\title{
Load Current Model of Electric Apparatus Based on Load Voltage Characteristics during Voltage Sag
}

\author{
Daisuke Iioka Member (Nagoya University) \\ Kenichiro Mori Student Member (Nagoya University) \\ Yasunobu Yokomizu Senior Member (Nagoya University) \\ Toshiro Matsumura Member (Nagoya University) \\ Masayuki Minowa Member (TOENEC Corporation)
}

Keywords: voltage sag, load modeling, load voltage characteristics, harmonics

This paper describes a measurement-based model of load current of electric apparatus after voltage sag occurrence. The terminal voltage and load current of a personal computer (PC), an inverter fluorescent light and an incandescent light were measured to find out the dependences of load characteristics on the voltage sag. We calculated load voltage characteristics $\alpha_{\mathrm{P}}$ and $\alpha_{\mathrm{Q}}$ using Eq. (1) and waveforms of voltage and current.

$$
\alpha_{\mathrm{P}}=\frac{\ln \left|\frac{P(t)}{P_{\mathrm{O}}}\right|}{\ln \left|\frac{V(t)}{V_{\mathrm{O}}}\right|}, \quad \alpha_{\mathrm{Q}}=\frac{\ln \left|\frac{Q(t)}{Q_{\mathrm{O}}}\right|}{\ln \left|\frac{V(t)}{V_{\mathrm{O}}}\right|}
$$

where $P_{\mathrm{O}}, Q_{\mathrm{O}}$ and $V_{\mathrm{O}}$ are active power, reactive power and voltage of load before the voltage sag occurrence, $P(t), Q(t)$ and $V(t)$ are active power, reactive power and voltage of load after voltage sag occurrence. Figure 1 shows time variations in the $\alpha_{\mathrm{P}}$ and $\alpha_{\mathrm{Q}}$ of the

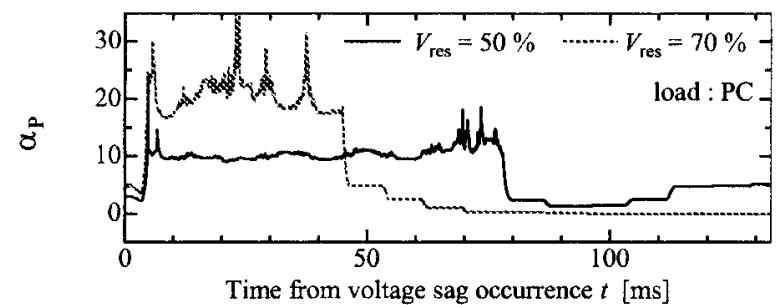

(a) Load parameter $\alpha_{\mathrm{P}}(t)$

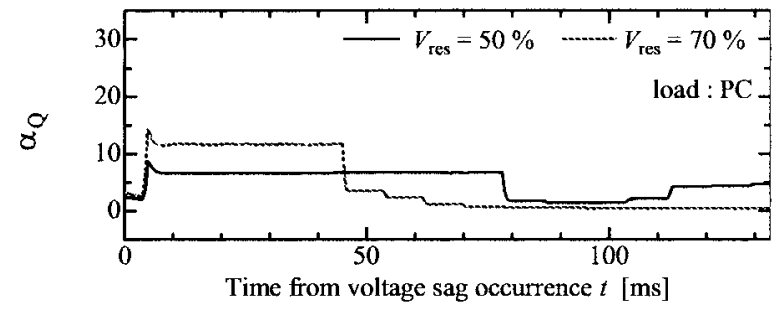

(a) Load parameter $\alpha_{\mathrm{Q}}(t)$

Fig. 1. Time variation in load parameters $\alpha_{\mathrm{P}}(t)$ and $\alpha_{\mathrm{Q}}(t)$ of PC load
PC load obtained by the voltage sag whose residual voltage are $50 \%$ and $70 \%$. It was found that the $\alpha_{\mathrm{P}}$ and $\alpha_{\mathrm{Q}}$ depend on the duration of the voltage sag and residual voltage.

In order to take account of transient load voltage characteristics, a modified exponential load current model is proposed. The load current waveform is estimated using Eq. (2), the database of harmonic component of load current and time variation in the parameters of load voltage characteristics $\alpha_{\mathrm{P}}(t)$ and $\alpha_{\mathrm{Q}}(t)$.

$$
\begin{aligned}
i_{\mathrm{E}}(t)= & \sum_{h=1}^{30} \sqrt{2} J_{h} \sin \left(2 \pi f h t-\theta_{h}\right) \\
& \times \frac{\sqrt{\left(\frac{P_{\mathrm{O}} V(t)^{\alpha_{\mathrm{P}}(t)}}{V(t) V_{\mathrm{O}} \alpha_{\mathrm{P}(t)}}\right)^{2}+\left(\frac{Q_{\mathrm{O}} V(t)^{\alpha_{\mathrm{Q}}(t)}}{V(t) V_{\mathrm{O}}{ }^{\alpha_{\mathrm{Q}}(t)}}\right)^{2}}}{\sqrt{1+\sum_{h=2}^{30} J_{h}{ }^{2}}}
\end{aligned}
$$

In Eq. (2), $J_{h}$ and $\theta_{h}$ are relative harmonic content and phase angle of load current, respectively. Two databases are obtained by the measurements of load terminal voltage and load current. Figure 2 shows the estimated load current of PC in case that the residual voltage is $45 \%$ or $75 \%$. The proposed load current model enables us to estimate the load current within an error of about $5 \%$ when the voltage sag occurs.

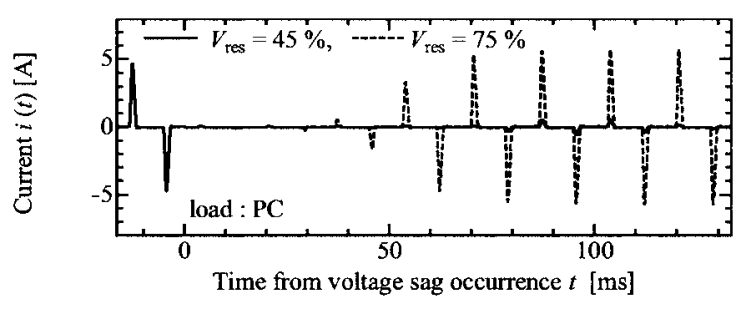

(a) Estimated waveforms

Fig. 2. Estimated waveforms of PC load current 


\title{
瞬時電圧低下時の負荷電圧特性を適用した単相負荷電流モデル
}

\author{
正 員 飯岡 大輔* 学生員 森 健一郎* \\ 上級会員 横水 康伸* 正 員 松村 年郎* \\ 正 員 箕輪 昌幸**
}

\section{Load Current Model of Electric Apparatus Based on Load Voltage Characteristics during Voltage Sag}

Daisuke Iioka*, Member, Kenichiro Mori*, Student Member, Yasunobu Yokomizu*, Senior Member, Toshiro Matsumura*, Member, Masayuki Minowa**, Member

This paper describes the measurement-based load current model of electric apparatus after a voltage sag occurrence. The terminal voltage and load current of a personal computer (PC), an inverter fluorescent light and an incandescent light were measured to find out the dependences of load characteristics on the voltage sag. The magnitude of the load current after voltage sag depends on both the magnitude of residual voltage and the time period of voltage sag. In order to make it possible to take account of these transient load characteristics in the power quality estimation, a load current model is proposed. The load current waveform is obtained using the database of harmonic component of load current and time variation in the parameters of load voltage characteristic. The proposed model enables us to estimate the load current within an error of about $5 \%$ when the voltage sag occur.

キーワード：瞬時電圧低下，負荷モデル，電圧特性指数，高調波

Keywords: voltage sag, load modeling, load voltage characteristics, harmonics

\section{1. まえがき}

高度情報化社会の進展に伴って計算機や電子機器などの 負荷が増加している。これらの負荷は瞬時電圧低下 (瞬低) により大きな影響を受けることが知られている。瞬低時の 負荷電流をモデル化することができれば，瞬低時における 電力供給設備内の電圧分布を詳細に再現することが可能と なる。これにより，瞬低対策機器の導入規模や制御手法が より明確になることが予想される。そこで，瞬低時の影響 を受けやすい負荷を多数有する受電設備内に扔ける電圧分 布を詳細に再現することを目的として，本論文では，瞬低 時における単相負荷機器への供給電流のモデル化手法を提 案する。

負荷モデルの検討例として，電力系統の安定度あるいは

\footnotetext{
* 名古屋大学大学院工学研究科電子情報システム専攻

T 464-8603 名古屋市千種区不老町

Department of Electrical Engineering and Computer Science, Nagoya University

Furo-cho, Chikusa-ku, Nagoya, 464-8603

**（株）トーエネック 技術開発室

干 457-0819 名古屋市南区滝春町 1-79

TOENEC Corporation

1-82, Takiharu-cho, Minami-ku, Nagoya 457-0819
}

電圧安定性に関する解析に使用される負荷モデルが広く知 られている(1) (4)。ここで，負荷は電圧特性指数と呼ばれる パラメータによりモデル化されている。一方，瞬低に対す る負荷挙動をモデル化する試みも発表されており, 瞬低発 生後の消費電力に過渡的な特性が含まれているという実測 例が報告されている(5)(6)。そのため, 瞬低を解析の対象とす るような負荷モデルを作成する場合，検討対象とする時間 幅は数十 $\mathrm{ms}$ から数 $\mathrm{s}$ 程度と短いが, 負荷の動特性を再現 する必要がある。また, 整流器などを内部に有する負荷は, 接続された電力系統にとって高調波源となるが，負荷電流 の高調波含有率を考慮した負荷の動特性モデルは, 筆者ら の知る限り提案例がない。

そこで，本論文で提案する単相負荷電流モデルは，単相 負荷の動特性を電圧特性指数の時間変化として扱うことに より作成したものである。本論文では，単相負荷の例とし て，パソコン，インバータ蛍光灯および白熱灯を使用した。 瞬低時における単相負荷機器の端子電圧および供給電流を 測定することにより, 単相負荷機器の過渡的な電圧特性を 明らかにした。この測定結果に基ついて，瞬低発生からの 時間および残存電圧の関数として電圧特性指数を表現する ことを提案する。さらに, 負荷電流の高調波含有率を負荷 の動特性モデルに反映させた数式モデルを導出した。 


\section{2. 負荷電圧および電流の実測}

〈2・1〉実験回路 Fig. 1 に実験回路を示す。交流電 源としてエヌエフ回路設計ブロック製電源環境シミュレー 夕 ES 2000U（2 kVA 三相マスタ）を使用した。周波数を $60 \mathrm{~Hz}$ とした。負荷機器としてパソコン (2001 年製造)，イ ンバータ蛍光灯あるいは白熱灯を使用した。パソコンは, その CPU 使用率が 100\%である使用状況下で試験を行っ た。インバータ蛍光灯および白熱灯の定格電力はそれぞれ $22 \mathrm{~W}$ および $100 \mathrm{~W}$ である。

定常状態から電圧低下を開始する電圧位相を $0 \mathrm{deg}$ とし, 負荷電圧を実効值で $100 \mathrm{~V}$ から $V_{\mathrm{res}}[\mathrm{V}]$ まで低下させた。 この $V_{\text {res }}$ を残存電圧と呼ぶこととする (7)。負荷電圧 $v(t)$ お よび負荷電流 $i(t)$ を測定した。測定機器として日置電機製 電源品質アナライザを用いた。

\section{$\langle\mathbf{2} \cdot \mathbf{2}\rangle$ 測定波形例}

$\langle\mathbf{2} \cdot \mathbf{2} \cdot \mathbf{1}\rangle \quad$ パソコンの測定結果 Fig. 2 に $t=0$ におい て $V_{\text {res }}$ を $50 \%$ あるいは $70 \%$ とした場合の電圧波形 $v(t)$ を 示す。このような瞬低が発生した場合のパソコンの電流波 形を Fig. 3 に示す。パソコンの電流波形は高調波を含んだ 歪み波形であった。

残存電圧 $V_{\text {res }}$ が $50 \%$ ある場合（Fig. 2 および 3 で破 線)，パソコンの動作が停止した。電圧低下直後に電流は流 れなくなった。その後, 電流は 6 サイクル目と 7 サイクル 目に流れるだけであった。

他方，残存電圧 $V_{\text {res }}$ が 70\%の場合（Fig. 2 および 3 で実 線), パソコンの動作は停止しなかった。電圧低下直後に電 流が流れなくなるのは $V_{\mathrm{res}}=50 \%$ の場合と同様であるが, 4 サイクル目以降において電流が流れた。また，5サイク ル目以降の電流ピーク值は, 電圧低下前の值よりも大きく なった。

残存電圧 $V_{\text {res }}$ を $0 \%$ から $90 \%$ の範囲で変えて同様の試験 を行ったところ，パソコンの負荷電流について次のことが 明らかになった。

- 電圧低下直後の数サイクルの間は電流が全く流れない。 また，残存電圧 $V_{\text {res }}$ が高いほど，再び電流が流れ始め る時刻が早くなる。

・残存電圧 $V_{\text {res }}$ が $60 \%$ 以下の場合はパソコンの動作が停 止する。

〈2·2·2〉 インバータ蛍光灯の測定結果 Fig. 4 にイ ンバータ蛍光灯の電流波形を示す。パソコンの電流波形と 同様に，インバー夕蛍光灯の電流波形は高調波を含んだ歪 み波形であった。残存電圧 $V_{\text {res }}$ が $50 \%$ あ゙る場合，電圧低 下直後に電流は流れなくなるが，3 サイクル目から流れ始 めた。一方， $V_{\text {res }}$ が 70\%である場合，電圧が低下してから 2 サイクル目以降で電流が流れた。

インバータ蛍光灯についても $0 \% \leq V_{\text {res }} \leq 90 \%$ 範囲で 同様の測定を行った結果，以下のことが分かった。

- 残存電圧 $V_{\text {res }}$ が $80 \%$ 以上である場合, 電圧低下直後に おいても電流は流れているが，その大きさは定常時よ

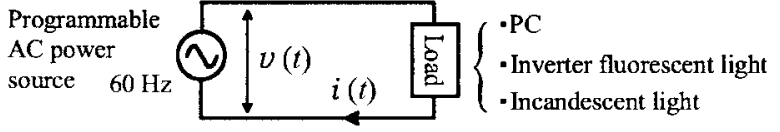

Fig. 1. Experimental circuit.

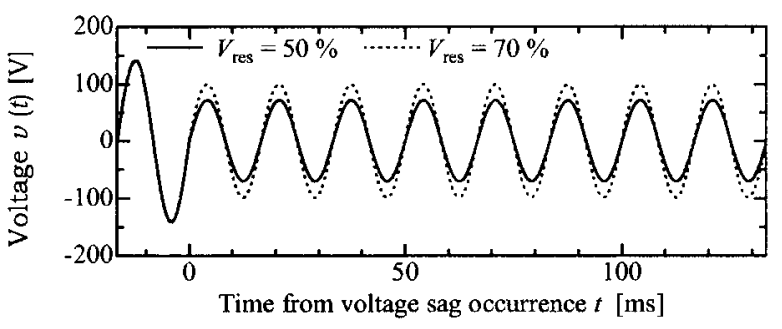

Fig. 2. Measured waveforms of voltage in case that residual voltage $V_{\text {res }}$ is $50 \%$ or $70 \%$.

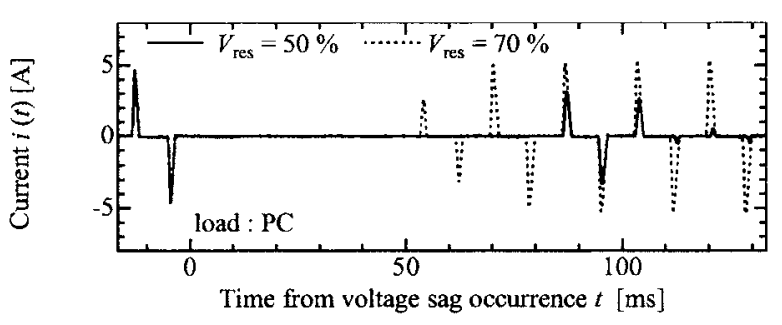

Fig. 3. Measured waveforms of PC load current in case that residual voltage $V_{\text {res }}$ is $50 \%$ or $70 \%$.

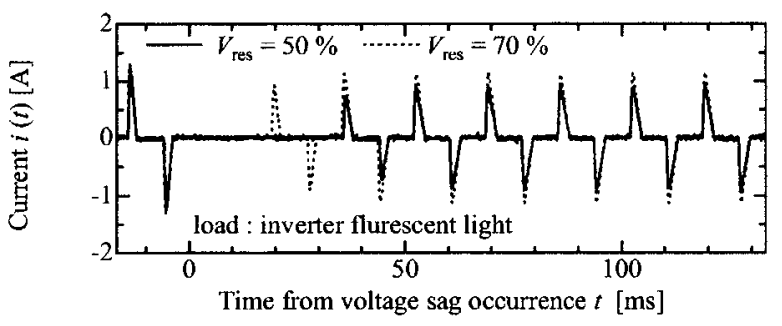

Fig. 4. Measured waveforms of inverter flurescent light load current in case that residual voltage $V_{\text {res }}$ is $50 \%$ or $70 \%$.

りも小さい。また，1 サイクル後には定常時の電流と 同じ大きさにまで復帰する。

- 残存電圧 $V_{\text {res }}$ が $70 \%$ 以下である場合，電圧低下直後か ら数サイクルの間, 電流が流れない。また，その後電 流が再び流れ始める時刻は, 残存電圧 $V_{\text {res }}$ が高いほど 早い。また，パソコンと比較すると，電流が再び流れ 始める時刻が早い。

・残存電圧の值に依存せず，インバータ蛍光灯の照度は 低下した。

$\langle\mathbf{2} \cdot \mathbf{2} \cdot \mathbf{3}\rangle$ 白熱灯の測定結果 Fig. 5 に白熱灯の電流 波形を示す。同図から，電圧低下時における負荷電流の波 形が電圧波形に比例していることが確認できた。この結果 から，白熱灯は定インピーダンス負荷であることが推測で きる。 


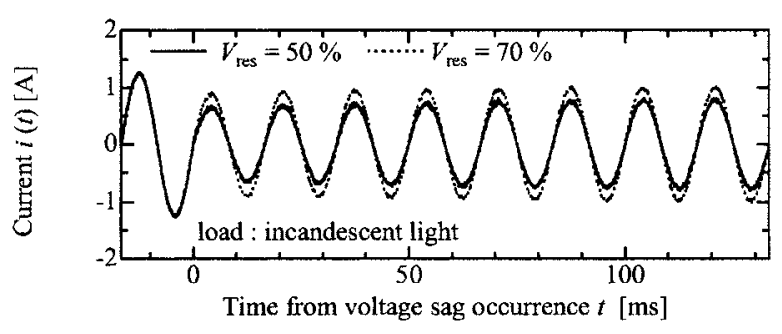

Fig. 5. Measured waveforms of incandescent light load current in case that residual voltage $V_{\text {res }}$ is $50 \%$ or $70 \%$.

\section{3. 電圧特性指数の計算}

Fig. $2 \sim$ Fig. 5 のように測定した負荷電圧 $v(t)$ および負 荷電流 $i(t)$ から, 負荷電圧の実効值 $V(t)$, 負荷電流の実効 值 $I(t)$ および負荷が消費する有効電力 $P(t)$ をそれぞれ次の ように計算した。ただし，前章での測定では， $t \geq 0$ におけ る $V(t)$ を一定值である $V_{\text {res }}$ としているが, 最終目標の負荷 モデルの適用範囲を広げる意味で, 電圧の実効值を (1) 式 で表すこととした。

$$
\begin{aligned}
& V(t)=\left(\frac{1}{T} \int_{t-T / 2}^{t+T / 2} v^{2}(t) d t\right)^{1 / 2} \\
& I(t)=\left(\frac{1}{T} \int_{t-T / 2}^{t+T / 2} i^{2}(t) d t\right)^{1 / 2} \\
& P(t)=\frac{1}{T} \int_{t-T / 2}^{t+T / 2} v(t) \cdot i(t) d t
\end{aligned}
$$

ここで，実効值を計算するための周期 $T$ を供給電圧の 1 サ イクルとし, $t-T / 2 \leq t \leq t+T / 2$ の範囲のデー夕を利用 して, 時刻 $t$ の実効值および電力を算出した。

$V(t), I(t)$ 㧍よび $P(t)$ を用いて, 負荷が消費する無効電 力 $Q(t)$ を次式により算出した。

$$
Q(t)=\sqrt{V^{2}(t) I^{2}(t)-P^{2}(t)} \quad[\mathrm{var}] .
$$

文献 (8) における負荷電力の電圧特性の定義を参考にし て, 筆者らは, 瞬低時の負荷電力の電圧特性を電圧特性指 数 $\alpha_{\mathrm{P}}$ および $\alpha_{\mathrm{Q}}$ を用いて次式で表すこととした。

$$
\frac{P(t)}{P_{\mathrm{O}}}=\left(\frac{V(t)}{V_{\mathrm{O}}}\right)^{\alpha_{\mathrm{P}}}, \quad \frac{Q(t)}{Q_{\mathrm{O}}}=\left(\frac{V(t)}{V_{\mathrm{O}}}\right)^{\alpha_{\mathrm{Q}}} .
$$

ここで $V_{\mathrm{O}}, P_{\mathrm{O}}$ および $Q_{\mathrm{O}}$ はそれぞれ瞬低前の電圧実効值, 負荷が消費する有効電力㧍よび無効電力である。 $\alpha_{\mathrm{P}}=0$ の とき負荷の有効電力は定電力特性であり, $\alpha_{\mathrm{P}}=1$ および $\alpha_{\mathrm{P}}=2$ のときはそれぞれ定電流特性抢よび定インピーダン ス特性である。無効分 $\alpha_{\mathrm{Q}}$ についても同様である。この意 味で $\alpha_{\mathrm{P}}$ および $\alpha_{\mathrm{Q}}$ は電圧特性指数と呼ばれている( ${ }^{(4)}$ 。

(5) 式の各式から $\alpha_{\mathrm{P}}$ および $\alpha_{\mathrm{Q}}$ を求めると, 次式を得る。

$$
\alpha_{\mathrm{P}}=\frac{\ln \left|\frac{P(t)}{P_{\mathrm{O}}}\right|}{\ln \left|\frac{V(t)}{V_{\mathrm{O}}}\right|}, \quad \alpha_{\mathrm{Q}}=\frac{\ln \left|\frac{Q(t)}{Q_{\mathrm{O}}}\right|}{\ln \left|\frac{V(t)}{V_{\mathrm{O}}}\right|} .
$$

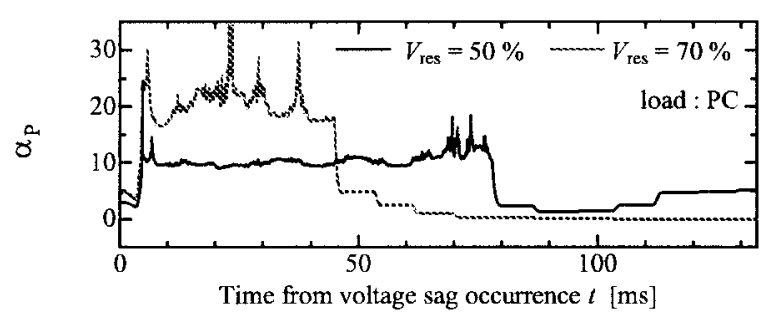

(a) Load parameter $\alpha_{\mathrm{P}}(\mathrm{t})$

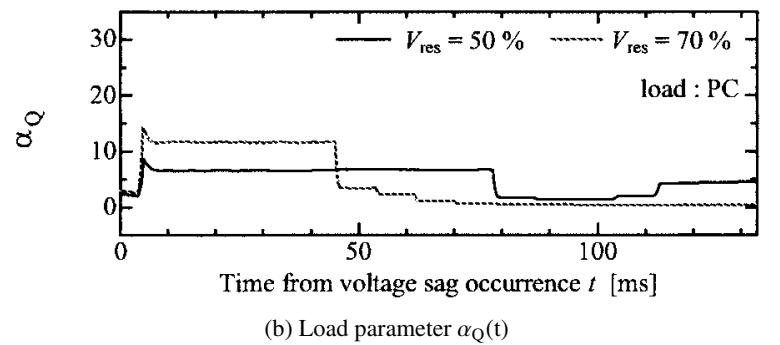

Fig. 6. Time variation in load voltage characteristics $\alpha_{\mathrm{P}}(t)$ and $\alpha_{\mathrm{Q}}(t)$ of PC load in case that residual voltage $V_{\text {res }}$ is $50 \%$ or $70 \%$.

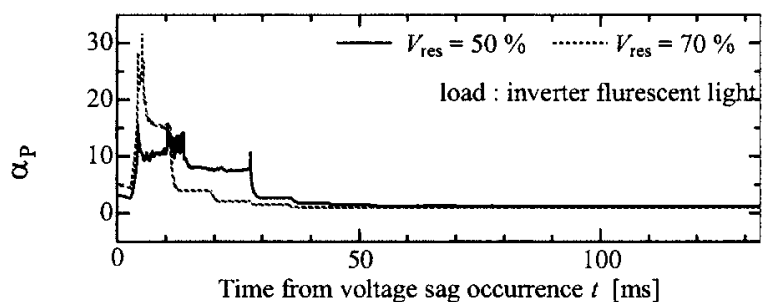

(a) Load parameter $\alpha_{\mathrm{P}}(t)$

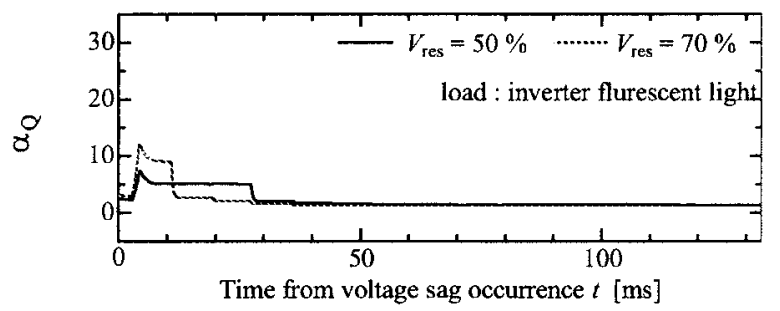

(b) Load parameter $\alpha_{\mathrm{Q}}(t)$

Fig. 7. Time variation in load voltage characteristics $\alpha_{\mathrm{P}}(t)$ and $\alpha_{\mathrm{Q}}(t)$ of inverter fluorescent light in case that residual voltage $V_{\text {res }}$ is $50 \%$ or $70 \%$.

例として, 残存電圧 $V_{\text {res }}$ が $50 \%$ および $70 \%$ の場合の パソコン負荷の $\alpha_{\mathrm{P}}$ および $\alpha_{\mathrm{Q}}$ を計算した。Fig. 2 および Fig. 3 に示す $v(t)$ 抢よび $i(t)$ の波形から，(1) (4) 式を用 いて， $V(t), P(t)$ 拉よび $Q(t)$ を算出し，これらを(6) 式に 代入すると， $\alpha_{\mathrm{P}}$ および $\alpha_{\mathrm{Q}}$ が求まる。計算結果を Fig. 6 に 示す。

Fig. 6(a)において, 電圧低下直後に $\alpha_{\mathrm{P}}$ が急激に増加し ているが，これは負荷電流が流れなくなることを示してい る。また, $V_{\mathrm{res}}=70 \%$ の場合, $t=40 \mathrm{~ms}$ 過ぎに $\alpha_{\mathrm{P}}$ が急激 に減少している。これは, 負荷電流が流れ始めることを示 している。

Fig. 6 から，パソコン負荷の $\alpha_{\mathrm{P}}$ および $\alpha_{\mathrm{Q}}$ は一定の值で はなく時間変化していることがわかった。また， $\alpha_{\mathrm{P}}$ および 


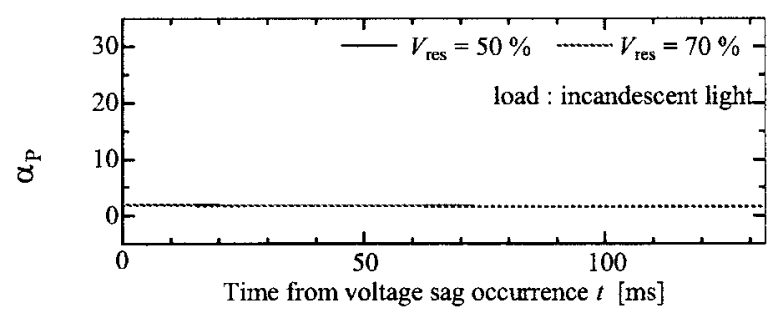

(a) Load parameter $\alpha_{\mathrm{P}}(t)$

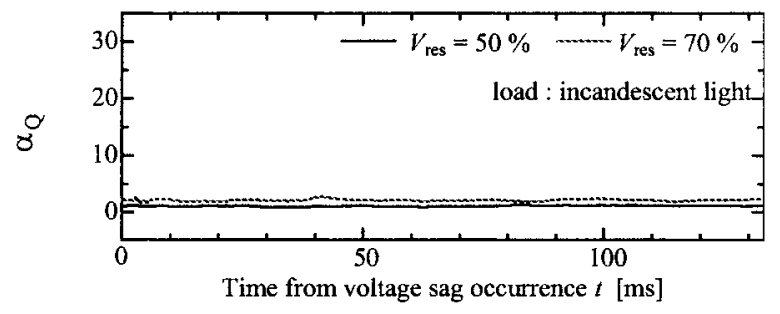

(b) Load parameter $\alpha_{\mathrm{Q}}(t)$

Fig. 8. Time variation in load voltage characteristics $\alpha_{\mathrm{P}}(t)$ and $\alpha_{\mathrm{Q}}(t)$ of incandescent light load in case that residual voltage $V_{\text {res }}$ is $50 \%$ or $70 \%$.

$\alpha_{\mathrm{Q}}$ の時間変化の様相は残存電圧 $V_{\mathrm{res}}$ によって異なること も明らかとなった。さらに，負荷電流が流れていない期間 に扔ける $\alpha_{\mathrm{P}}$ および $\alpha_{\mathrm{Q}}$ は，流れている期間に比べて大きな 值になることも確認できた。

インバー夕蛍光灯負荷および白熱灯負荷についても $\alpha_{\mathrm{P}}$ お よび $\alpha_{\mathrm{Q}}$ を算出し，結果を Fig. 7 および Fig. 8 に示した。 Fig. 7 から，インバー夕蛍光灯負荷の $\alpha_{\mathrm{P}}$ 抢よび $\alpha_{\mathrm{Q}}$ の時間 変化について，パソコン負荷の場合と同じことが言える。 また, Fig. 8 に示す白熱灯負荷の $\alpha_{\mathrm{P}}$ および $\alpha_{\mathrm{Q}}$ は瞬低発生 からの時間䇽よび残存電圧に依存しない一定の值となって いる。また，それらの值は約 2 であることから，白熱灯は 定インピーダンス特性であることが確認できる。

\section{4. 負荷電流の高調波含有率と位相の調査}

負荷電流に含まれる高調波を解析するため，測定した電 流波形 $i(t)$ を高速フーリエ変換（FFT：Fast Fourier Transform）した。残存電圧が 70\%であるパソコンの負荷電流を 調査した。本論文では，高調波含有率が $1 \%$ 未満となる次 数の高調波電流はその影響が小さいものとして，それらを 無視した。

電圧低下発生前と発生後の高調波含有率を比較すると, 数\%の違いがあった。また，電圧低下発生後における高調 波含有率は時々刻々と変化することもあきらかとなった。 詳細にモデル化することを考えると，高調波含有率打よび 位相が時間変化することを考慮してモデル化する必要があ るが，本論文では，モデルの煩雑化を避けるために，電圧 低下発生前の電流波形から高調波含有率拉よび位相を算出 し，それを電圧低下時の高調波モデルとして使用すること とした。Fig. 9 に，パソコン負荷の電流から算出した高調 波含有率扮よび位相を示している。同様に，Fig. 10 には， インバータ蛍光灯について算出した高調波含有率扔よび位

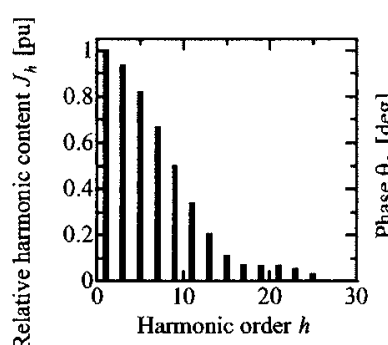

(a) Relative harmonic content $J_{h}[\mathrm{pu}]$

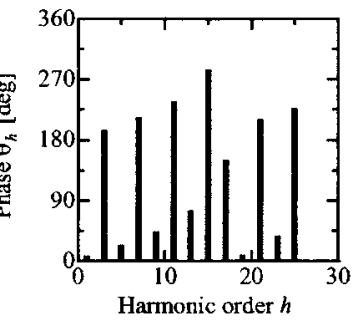

(b) Phase [deg]
Fig. 9. Relative harmonic content $J_{h}$ and phase angle $\theta_{h}$ of PC load current.

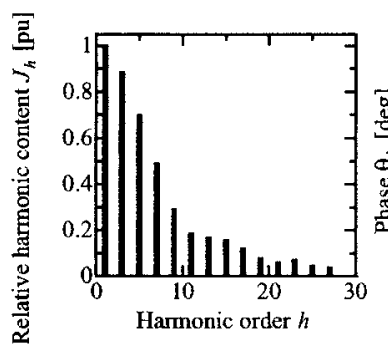

(a) Relative harmonic content $J_{h}[\mathrm{pu}]$

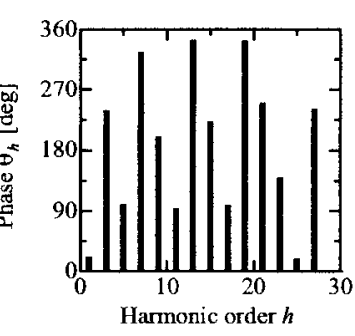

(b) Phase [deg]
Fig. 10. Relative harmonic content $J_{h}$ and phase angle $\theta_{h}$ of inverter flurescent light load current.

相を示している。

\section{5. 負荷電流のモデル化に対する考察}

第 2 章において，白熱灯の負荷電流は高調波を含まない 正弦波であったが，パソコンおよびインバー夕蛍光灯の負 荷電流は高調波を含む歪み波形であったことを示した。ま た，第 3 章において電圧特性指数を調べたところ，白熱灯 は定インピーダンス特性を示したが，パソコンやインバー 夕蛍光灯負荷の場合，残存電圧および瞬低発生からの時間 に依存することが明らかになった。

以上の結果を踏まえて負荷をモデル化することを考えた 場合，白熱灯に代表される定インピーダンス特性を有する 負荷は抵抗負荷として容易にモデル化できる。一方，パソ コンやインバー夕蛍光灯のような負荷については, 残存電 圧抢よび瞬低発生からの時間に依存した電圧特性指数や負 荷電流の高調波を考慮する必要がある。

そこで，電圧特性指数を時間の関数として扱うことを提 案する。すなわち，(5) 式は次のように書き表される。

$$
\frac{P(t)}{P_{\mathrm{O}}}=\left(\frac{V(t)}{V_{\mathrm{O}}}\right)^{\alpha_{\mathrm{P}}(t)}, \frac{Q(t)}{Q_{\mathrm{O}}}=\left(\frac{V(t)}{V_{\mathrm{O}}}\right)^{\alpha_{\mathrm{Q}}(t)}
$$

パソコン負荷, インバータ蛍光灯負荷, 白熱灯負荷に対 して, 残存電圧 $V_{\mathrm{res}}$ を $0,10,20,30,40,50,60,70$, 80 および $90 \%$ とした場合の瞬低試験を実施し, 各 $V_{\text {res }}$ に 対して, 瞬低からの経過時間と $\alpha_{\mathrm{p}}(t)$ および $\alpha_{\mathrm{Q}}(t)$ の関係を 得た。これを電圧特性指数データベースとして次章に示す 負荷モデルに適用する。 


\section{6. 電流源による負荷のモデル化}

第 $h$ 調波の電流源を $h=1 \sim 30$ まで並列接続したもの の合成電流を用いて負荷への供給電流を表すこととした。 合成電流の瞬時值を $i_{\mathrm{E}}(t)$ とする。第 $h$ 調波の電流実効值 $I_{h}(t)$ を用いると, $i_{\mathrm{E}}(t)$ は次式で表される。

$$
i_{\mathrm{E}}(t)=\sum_{h=1}^{30} \sqrt{2} I_{h}(t) \sin \left(2 \pi f h t-\theta_{h}\right) .
$$

電流瞬時值 $i_{\mathrm{E}}(t)$ の実効值 $I(t)$ は，第 $h$ 調波の高調波含有 率 $J_{\mathrm{h}}$ を用いると次式により算出される。

$$
I(t)=I_{1}(t) \sqrt{1+\sum_{h=2}^{30} J_{h}{ }^{2}}
$$

ただし, $I_{1}(t)$ は基本波電流の実効值である。(9) 式に $I_{1}(t)=$ $I_{h}(t) / J_{h}$ を代入し， $I_{h}(t)$ について解くと次式を得る。

$$
I_{h}(t)=\frac{I(t) J_{h}}{\sqrt{1+\sum_{h=2}^{30} J_{h}{ }^{2}}}
$$

一方，(4) 式および (7) 式から $I(t)$ について解くと,

$$
I(t)=\sqrt{\left(\frac{P_{\mathrm{O}} V(t)^{\alpha_{\mathrm{P}}(t)}}{V(t) V_{\mathrm{O}}{ }^{\alpha_{\mathrm{P}}(t)}}\right)^{2}+\left(\frac{Q_{\mathrm{O}} V(t)^{\alpha_{\mathrm{Q}}(t)}}{V(t) V_{\mathrm{O}} \alpha_{\mathrm{Q}}(t)}\right)^{2}}
$$

(11) 式を(10) 式に代入すると，

$$
I_{h}(t)=\frac{J_{h} \sqrt{\left(\frac{P_{\mathrm{O}} V(t)^{\alpha_{\mathrm{P}}(t)}}{V(t) V_{\mathrm{O}} \alpha_{\mathrm{P}(t)}}\right)^{2}+\left(\frac{Q_{\mathrm{O}} V(t)^{\alpha_{\mathrm{Q}}(t)}}{V(t) V_{\mathrm{O}} \alpha_{\mathrm{Q}}(t)}\right)^{2}}}{\sqrt{1+\sum_{h=2}^{30} J_{h}{ }^{2}}}
$$

(12) 式を(8) 式に代入すると,

$$
\begin{aligned}
& i_{\mathrm{E}}(t)=\sum_{h=1}^{30} \sqrt{2} J_{h} \sin \left(2 \pi f h t-\theta_{h}\right) \\
& \times \frac{\sqrt{\left(\frac{P_{\mathrm{O}} V(t)^{\alpha_{\mathrm{P}}(t)}}{V(t) V_{\mathrm{O}}{ }^{\alpha_{\mathrm{P}}(t)}}\right)^{2}+\left(\frac{Q_{\mathrm{O}} V(t)^{\alpha_{\mathrm{Q}}(t)}}{V(t) V_{\mathrm{O}} \alpha_{\mathrm{Q}}(t)}\right)^{2}}}{\sqrt{1+\sum_{h=2}^{30} J_{h}^{2}}}
\end{aligned}
$$

(13) 式が負荷への供給電流モデルを表している。第 $h$ 調波 の高調波含有率 $J_{h}$ および位相 $\theta_{h}$ に対して，第 4 章で示し た高調波成分データベースの值を代入する。電圧特性指数 $\alpha_{\mathrm{P}}(t)$ および $\alpha_{\mathrm{Q}}(t)$ には，電圧特性指数データベースから， 負荷端の電圧実効值 $V(t)$ および瞬低発生からの時間に対応 した值を代入する。その結果，(13) 式から瞬低後における
負荷電流瞬時值が決定される。

例として， $\alpha_{\mathrm{P}}(t)$ および $\alpha_{\mathrm{Q}}(t)$ がデータベースに収録され ていない $V_{\text {res }}=45 \%$ およ゙ $75 \%$ 場合について，パソコ ンの負荷電流を提案モデルを用いて推定した。計算結果を

Fig. 11(a)に示す。

計算にはEMTDC を用いた。データベースにない電圧特 性指数 $\alpha_{\mathrm{P}}(t)$ および $\alpha_{\mathrm{Q}}(t)$ は直線補間することで模擬した。 提案モデルによる負荷電流推定值の精度を検証するため に, $V_{\mathrm{res}}=45 \%$ および $75 \%$ のときのパソコン負荷電流を 実測した。測定結果を Fig. 11(b) に示す。Fig. 11(a)の推定 電流は Fig. 11(b) の実測電流に良く一致している。負荷電 流推定值の精度を定量的に示すために, 瞬低期間中におけ る測定值と推定值との誤差 $\varepsilon$ を次式により計算した。

$$
\varepsilon=\frac{1}{N} \sum_{i=1}^{N}\left(\left|i_{\mathrm{m}, i}-i_{\mathrm{e}, i}\right|\right)
$$

ここで, $i_{\mathrm{m}, i}$ および $i_{\mathrm{e}, i}$ は, 測定電流および推定電流の $i$ 番 目のサンプリング值である。また, 瞬低期間中にサンプリ ングした総数を $N$ とした。 $V_{\mathrm{res}}=45 \%$ おび $75 \%$ にい

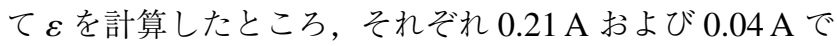
あった。平常時における負荷電流の最大值に対する $\varepsilon$ の割 合を誤差と定義すると, 平常時における PC の電流最大值は $4.75 \mathrm{~A}$ であったので，誤差は $0.9 \%$ おび $4.4 \%$ となった。 また，この誤差の結果は，データベース作成時の電圧低下 試験を $10 \%$ 刻みで実施した場合の誤差を表している。デー タベース作成時の実験条件として $10 \%$ 程度刻みで実験を実 施すれば，誤差は 5\%程度となることを示唆している。

インバータ蛍光灯を負荷として用いた場合についても同 様の検討を行った。Fig.12(a) および (b) には， $V_{\text {res }}=45 \%$ お よび 75\%のときの負荷電流推定值および実測值をそれぞれ 示している。同図から $\varepsilon$ を算出したところ， $V_{\text {res }}=45 \%$ の 場合は $0.06 \mathrm{~A}$ であり $V_{\text {res }}=75 \%$ の場合は $0.08 \mathrm{~A}$ であった。

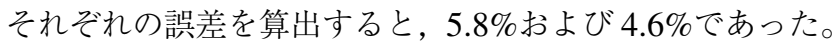

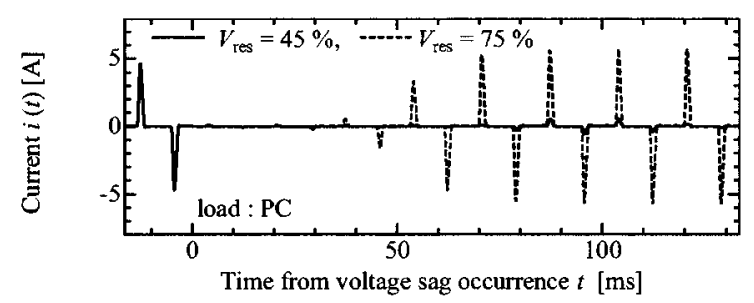

(a) Estimated waveforms

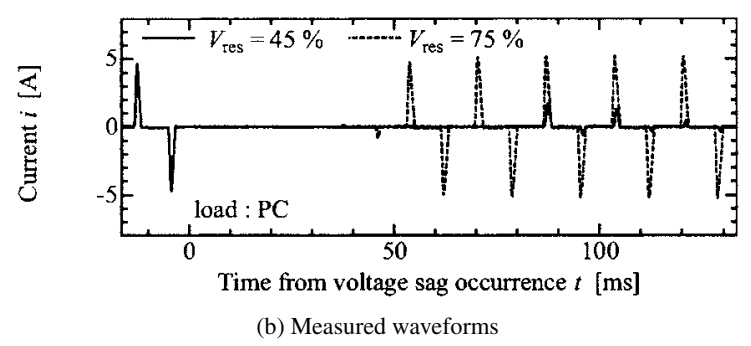

Fig. 11. Estimated and measured waveforms of PC load current in case that residual voltage $V_{\text {res }}$ is $45 \%$ or $75 \%$. 


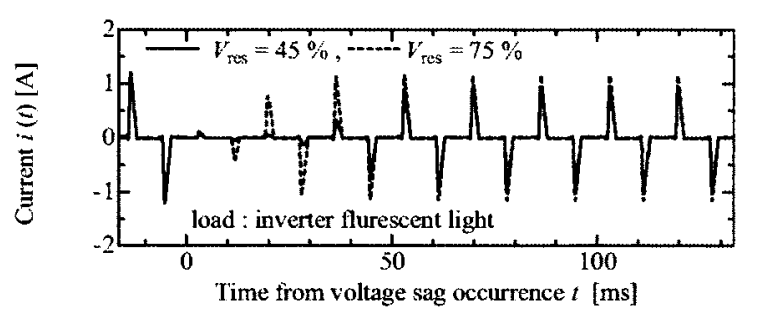

(a) Estimated waveforms

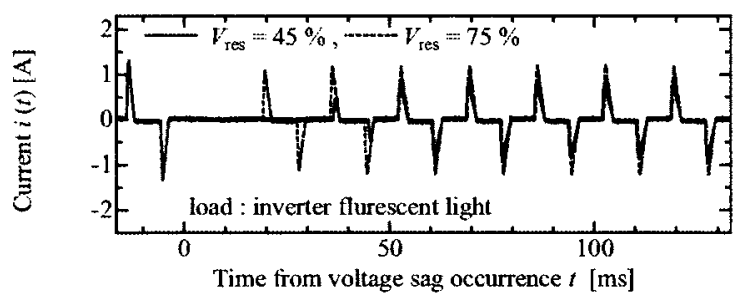

(b) Measured waveforms

Fig. 12. Estimated and measured waveforms of inverter flurescent light load current in case that residual voltage $V_{\text {res }}$ is $45 \%$ or $V_{\text {res }}=75 \%$.

以上の結果から，本提案手法を用いると約 $5 \%$ 程度の誤 差で，瞬低期間中の負荷電流を推定できることが明らかと なった。

また，Fig. 11 で示される残存電圧 $V_{\text {res }}$ が $45 \%$ 瞬低が 発生したとき，パソコン負荷の電流は瞬低発生後 $120 \mathrm{~ms}$ 以 後は流れていないので, 負荷脱落が確認できる。提案モデ ルは，データベースを基に電圧低下発生直後の動的な電流 の時間変化を再現できる。

本論文では，単相負荷を対象とした負荷電流モデルにつ いて述べたが，同様の手法は動力負荷に対しても適用でき ると考えられる。

\section{7. あとがき}

本論文では，パソコン，インバータ蛍光灯および白熱灯 の瞬低時における電圧特性を明らかにした。白熱灯は定イ ンピーダンス特性を示したが，パソコンやインバータ蛍光 灯負荷の場合，瞬低時の負荷電流は，残存電圧および瞬低 発生からの時間に依存することが明らかになった。そこで, 負荷の電圧特性指数の時間変化に着目して, 瞬低時におけ る負荷電流の時間変化を再現するモデルを作成した。すな わち，瞬低発生から経過時間および残存電圧に対応する電 圧特性指数のデータベースを構築した。また，高調波電流 含有率および位相のデータベースを作成した。そして，負 荷電流瞬時值の時間変化を再現する式を導出し，両デー夕 ベースの值を代入することにより，実測值との誤差が $5 \%$ 程 度の推定值を算出することを明らかとした。

(平成 18 年 9 月 1 日受付，平成 19 年 1 月 23 日再受付)

\section{文献}

（1）浅田 実·長尾待士 ·田村信次・杉浦徳廣：「大幅電圧変動時の負荷 特性一負荷特性の統計的検討 $-」$, 電気学会電力技術研資, PE-86-32

(1986-8)

(2) K. Tomiyama: "Estimation of Voltage Sensitivity of Bus Load for Power System Analysis", T.IEE Japan, Vol.119-B, No.3, pp.327-332 (1999-3) (in Japanese)

富山勝幸 :「系統解析のための静的負荷特性の推定手法」, 電学論 B, 119, 3, pp.327-332 (1999-3)

(3) K. Tomiyama: "Modeling Load Dynamics for Power System Analysis", T. IEE Japan, Vol.119-B, No.6, pp.697-703 (1999-6) (in Japanese) 富山勝幸：「系統解析のための「動的負荷モデル」の検討」, 電学論 B, 119, 6, pp.697-793 (1999-6) (2001)

(4) M. Asada and K. Yamashita: "An Analysis of the Present Load Characteristic in Japan $60 \mathrm{~Hz}$ System", T. IEE Japan, Vol.121-B, No.10, pp.13711378 (2001-10) (in Japanese)

浅田 実・山下光司:「わが国 $60 \mathrm{~Hz}$ 系統における負荷特性の実態分 析」, 電学論 B, 121, 10, pp.1371-137 (2001-10) (2001)

(5) K. Tomiyama: "Analysis and Tests on Voltage Characteristics of AirConditioners", T. IEE Japan, Vol.120-B, No.10, pp.1223-1230 (2000-10) (in Japanese)

富山勝幸 :「家庭用エアコンの電圧特性試験と考察」, 電学論 B, 120, 10, pp.1223-1230 (2000-10)

(6) M. Yamashita, N. Kanao, and K. Mizuno: "A Study of Voltage Dynamic Characteristics of Load Devices by Voltage Dip Generator", 2003 National Convention Record IEE Japan, No.6, pp.138-139 (2003-3) (in Japanese) 山下益功·金尾則一・水野弘一:「瞬低発生装置を用いた負荷機器の電 圧動特性に関する一考察」, 平成 15 年電気学会全国大会, pp.138-139 (2003-3)

（7）電気協同研究会 編：「配電系統に扔ける電力品質の現状と対応技 術」, 電気協同研究, Vol.60, No.2, p.235 (2005)

(8) P. Kundur: "Power System Stability and Control", EPRI, Power Engineering Series, pp.271-313, McGraw-Hill (1994)

飯 岡大 輔
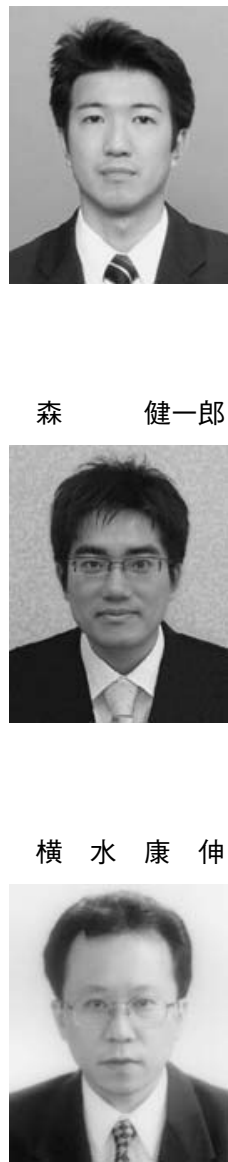

（正員） 2004 年 3 月名古屋大学大学院工学研究 科電気工学専攻博士課程後期課程修了。同年 4 月 同大学大学院工学研究科電子情報システム専攻助 手, 現在に至る。博士 (工学)。分散型電源が導 入された電力系統における電力品質に関する研究 に従事。電気設備学会，IEEE 会員。 
松 村 年 郎 (正員) 1979 年 3 月 名古屋大学大学院工学研究 科博士課程後期課程満了。同年 4 月 同大学助手, 1987 年 2 月 同大学講師。1 1989 年 3 月 京都大学講 師。1 1992 年 1 月 名古屋大学助教授，1995 年 4 月 同大学教授，現在に至る。工学博士。主として， 大電流遮断，電気エネルギーの有効利用に関する 研究に従事。IEEE 会員。
箕 輪 昌 幸 (正員) 1989 年 3 月信州大学工学部電気工学科

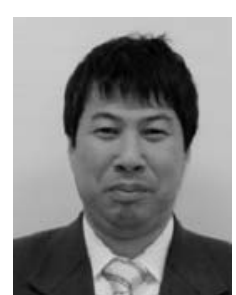
卒業。1994 年 3 月名古屋大学大学院工学研究科電 気工学専攻博士課程後期課程満了。同年 4 月 (株) トーエネック入社, 現在に至る。博士 (工学)。主 として，電気設備の雷害対策，電源品質および接 地技術に関する研究開発に従事。電気設備学会, 電子情報通信学会会員。 